Please do not remove this page

RMIT

UNIVERSITY

\title{
Calibrating the PhD for Industry 4.0: global concerns, national agendas and Australian institutional responses
}

Molla, Tebeje; Cuthbert, Denise

https://researchrepository.rmit.edu.au/esploro/outputs/9921858979501341/filesAndLinks?institution=61RMIT_INST\&index=null

Molla, T., \& Cuthbert, D. (2019). Calibrating the PhD for Industry 4.0: global concerns, national agendas and Australian institutional responses. Policy Reviews in Higher Education, 3(2), 167-188.

https://doi.org/10.1080/23322969.2019.1637772

Document Version: Accepted Manuscript

Published Version: https://doi.org/10.1080/23322969.2019.1637772

Repository homepage: https://researchrepository.rmit.edu.au

(C) 2019 Society for Research into Higher Education

Downloaded On 2023/04/26 22:39:04 +1000 
Thank you for downloading this document from the RMIT Research Repository.

The RMIT Research Repository is an open access database showcasing the research outputs of RMIT University researchers.

RMIT Research Repository: http://researchbank.rmit.edu.au/

\section{Citation:}

Molla, T and Cuthbert, D 2019, 'Calibrating the PhD for Industry 4.0: global concerns, national agendas and Australian institutional responses', Policy Reviews in Higher Education, vol. 3, no. 2, pp. 167-188.

See this record in the RMIT Research Repository at:

https://researchbank.rmit.edu.au/view/rmit:54885

Version: Accepted Manuscript

Copyright Statement:

(C) 2019 Society for Research into Higher Education

\section{Link to Published Version:}

https://dx.doi.org/10.1080/23322969.2019.1637772 


\title{
Calibrating the PhD for Industry 4.0: Global Concerns, National Agendas and Australian Institutional Responses
}

\begin{abstract}
Globally, the demands of Industry 4.0 (or the Fourth Industrial Revolution) for a future-ready skilled workforce have placed significant political pressure on $\mathrm{PhD}$ programs to deliver different sorts of graduates. The paper documents the prevalent "skills gap" narrative of global policy actors and, and using a multi-scalar policy lens, examines global and national research-training policy debates and Australian institutional responses to calls to transform the PhD to make it more amenable to the new economic conditions. We provide a survey and analysis of recent institutional changes to the PhD in Australia and find that these fall into three overlapping categories: increased employability skills training; the development of industry- and end-user engaged programs; and flexible pathways to the PhD. Following this analysis, we step back to ask some critical questions of these developments both in terms of how effectively they answer the challenges put out in Industry 4.0 discourses and the problematic assumptions, silences and omissions in the policy debates and university responses. We conclude with some critical reflections on the limitations of prevalent human capital logic underpinning PhD reform and ask whether a capability approach to human development may prove a more useful evaluative framework for responsiveness of the PhD, especially to the range of challenges, beyond the economic, which this new epoch promises. We argue that PhD graduates should not only be prepared to meet the demands of Industry 4.0 but also to lead us through the socio-economic transformations this revolution may entail.
\end{abstract}

Keywords: Australia, Industry 4.0, Fourth Industrial Revolution, Skills Gap, PhD Reform, Industry Engagement, Graduate Capability

\section{Introduction}

Fast-paced technological advances coupled with globalization have exerted pressure on education systems worldwide. According to global policy actors such as the World Economic Forum (WEF), we are entering the Fourth Industrial Revolution (or Industry 4.0), which is characterized by advances in artificial intelligence and machine learning as well as intensive knowledge work (Schwab, 2016, 2017). The key feature of Industry 4.0 is "the marriage of physical and digital technologies such as analytics, artificial intelligence, cognitive technologies and the internet of things (IoT)" (Deloitte, 2018, p.2). In this "Transformative Age" (Ernst \& Young, 2018), we are witnessing the emergence of "digital jobs" and "thinking machines". This has significant implication for how we learn, work, live and relate to each other. Drawing on a global survey of leaders of big companies and businesses in 19 countries, Deloitte $(2018$, p.3) concludes: "Executives lack confidence that they have the right talent in place to be successful in Industry 4.0". Hence, as a recent report (Ernst \& Young, 2018) notes, the critical question that higher education policymakers should address are: "How will universities contribute to solving the challenges of the Transformative Age?" (p.1) and, fundamentally, "When machines become workers, what do humans do?" (p.7). Changes in higher education policy and practice are also positioned in relation to other disruptive elements. These include the involvement of non-university actors in doctoral training and the rise of what has been termed eduscepticism (Cowan, 2017). Eduscepticism combines anti-intellectualism with populist opposition to evidence-based science on a range of issues, most centrally climate change. For 
edusceptics (e.g. Bauerlein, 2008; Caplan, 2018; Sykes, 2016; Whitaker, 2004), higher education is a waste of time and money.

Amid such dramatic technological and economic transformation and disruptive trends and discourses, critical appraisals are being made of the relevance, efficiency and quality of the PhD. The capacity of the PhD to meet the expressed and perceived expectations of internal and external stakeholders is central to policy debates at global, national and institutional levels. Since our last publication (Cuthbert \& Molla, 2015) much has changed in the pace of doctoral education, both at discursive and practical levels. In 2015, we argued that the PhD was in the throes of a discursive "crisis" for which empirical evidence was mixed and somewhat scant. We analysed policy questions on the function of the PhD, explored expectations imposed upon it by knowledge economy and innovation imperatives, and reflected on the quality of the degree itself and the outcomes of its graduates, about which still not enough is known. Reviewing those earlier arguments in the light of developments in the intervening four years, the present article finds that far from being resolved, the PhD crisis appears to have deepened. In this paper, with global concerns about the skills gap associated with Industry 4.0 as a background, we examine recent national policy discourses and institutional responses in Australia in the area of research training, specifically the $\mathrm{PhD}$. The analysis answers the following research question: how is the $\mathrm{PhD}$ responding to disruptive trends in the higher education sector?

Methodologically, the paper is informed by a multi-scalar view of policy. Such a view maintains that education policy agendas in the globalizing world are no longer "territorially bound within nationstates" (Lingard \& Rawolle, 2011, p.489). Often the articulation of educational politics and policymaking is global and national at the same time. In light of the knowledge economy agenda that has pervaded "the global education policy field" (Rizvi \& Lingard, 2010), national governments are increasingly under pressure to make their education system more efficient, responsive and innovative. The global frame of reference of policy agendas enables national actors "to act in rather more omnipotent ways-where the global scale is invoked as a higher form of authority and rule" (Robertson \& Dale, 2016, p.40). As a result, local resistance tends to be smothered and policy projects advance quickly. One of the methodological implications is that analysis of national and institutional changes needs to consider prevalent agendas at the supranational level. Based on this assumption, in this paper, we have positioned publicly available national and institutional policy documents in relation to the ongoing discourse on the skills gap in doctoral graduates and the skills requirements of future jobs.

As the discourse of the Fourth Industrial Revolution is emerging, it is not yet possible to document how other comparable economies have responded to the 'skills gap' concern in the global policy space. Hence our analysis of institutional responses is restricted to Australian exemplars; this is a limitation of the study. Nonetheless, given the increasing policy convergences of doctoral programs within OECD nations (see Andres et al., 2015; Barnett et al., 2017; Gokhberg et al., 2016; Shin et al., 2018; Ryan, 2012), many of the observations made are likely to be generalisable to comparable higher education systems. Also, the paper is part of preparatory research for a larger empirical study that, with global and regional developments as a backdrop, closely investigates the $\mathrm{PhD}$ reform in Australia. The future research aims at problematising how the global Industry 4.0 discourse is mobilised and mutated in the context of national and institutional policy spaces.

The following discussion is organised in five sections. The first summarises key elements of global discourses on the skills gap and productivity. The second reflects on national responses within Australia to these global discourses, while the third focuses on selected Australian institutional responses to national debates on research training policies and practices. The fourth section problematises the issue framings, followed by another section that proposes a capability-based 
assessment of the value of research training as an alternative to prevalent human capital assumptions. We close the paper with some reflections and policy directions.

\section{Global Concerns: Skills for Future Jobs}

Few people might be convinced by the prospects of a 'workless' future (Dunlop, 2016), an accelerated computerization of work (Frey \& Osborne, 2013; Brynjolfsson \& McAfee, 2016), or hyper-automation of white-collar jobs and subsequent 'globotics upheaval' (Baldwin, 2019). Nonetheless, it is undeniable that advances in technologies of production and distribution are transforming job profiles and skills requirements in the workplace. In the face of the rapid pace of economic and technological transformation, the gap between the skills of the workforce and those needed for future jobs has become a global policy concern (see, for example, European Commission [EC], 2010, 2011; International Labour Organization [ILO] , 2011; Organization for Economic Development and Cooperation [OECD], 2017a, 2017b, 2018; United Nations Educational, Scientific and Cultural Organization [UNESCO], 2015; World Bank, 2018, 2019; WEF, 2016).The global concern regarding the future of work and economic productivity revolves around the notion of Industry 4.0. Drath \& Horch (2014) establish that the term Industry 4.0 first emerged at the Hanover Fair in Germany in 2011 to refer to emerging "cyber-physical production systems" in the manufacturing sector, which are characterised by smart machines that can exchange information and trigger action. Since then, the concept has become a key policy frame. In the global policy space, the key champion of the Fourth Industrial Revolution, Industry 4.0, is the World Economic Forum (WEF, 2016; Schwab, 2015, 2017). Klaus Schwab, founder and executive chairman of the World Economic Forum (WEF), explains the concept of the Fourth Industrial Revolution:

The First Industrial Revolution used water and steam power to mechanize production. The Second used electric power to create mass production. The Third used electronics and information technology to automate production. Now a Fourth Industrial Revolution is building on the Third, the digital revolution that has been occurring since the middle of the last century. It is characterized by a fusion of technologies that is blurring the lines between the physical, digital, and biological spheres. (Schwab, 2015, para.2, emphasis added)

In the Future of Jobs, the $\operatorname{WEF}(2016$, p.7) holds that "[f]or a talent revolution to take place, governments and businesses will need to profoundly change their approach to education, skills and employment, and their approach to working with each other". The Forum calls upon governments to ensure the relevance of education to the needs and aspirations of their societies. It observes, "[m]ost existing education systems at all levels provide highly siloed training and continue a number of 20th century practices that are hindering progress on today's talent and labour market issues" (p.8). Schwab (2017) further argues that without a proper policy intervention, the Fourth Industrial Revolution may lead to increased inequality and instability. In its diagnosis of the impact of advances in artificial intelligence, machine learning and automation, the WEF notes:

Beyond hard skills and formal qualifications, employers are often equally concerned about the work-related practical skills or competences that current employees (or prospective new hires) are able to use in order to perform various job tasks successfully. [...] On average, by 2020, more than a third of the desired core skill sets of most occupations will be comprised of skills that are not yet considered crucial to the job today. (p.20) 
Similarly, other global policy actors call for attention to the emerging problem of the skills gap. In the 2016 Cancún Ministerial meeting on the Digital Economy in Mexico (2016), in Getting Skills Right (2018a) and the Education 2030 framework (2018b), the OECD acknowledges that in the context of intensified globalization, demographic shifts and technological advances, the knowledge and skills needed in the labour market are changing. The profound economic changes and technological innovation underway mean that member states need to develop strategic responses to "disruptive waves of change in every sector" (OECD, 2018b, p.3). When it comes to the link between doctoral education, research and innovation, the OECD (2017b) stresses the importance of promoting scientific research skills through doctoral training, which "plays a crucial role in innovation and economic growth and contributes significantly to the national and international knowledge base" ( $p$. 279). It also recognises the importance of equipping researchers for a broad range of work situations, urging research training providers to integrate employability skills such as communication, problem-solving, team-working and networking, and business and management expertise into the curriculum (OECD, 2012).

Likewise, in its Education 2020 Strategy, the World Bank (2011) emphasizes the importance of improving the labor market relevance of education. In its latest World Development Report, The Changing Nature of Work, the Bank calls for governments to align university-based research with industry needs and thereby support a "healthy innovation ecosystem" (World Bank, 2019, p.81). The Bank underscores that improved public investment in human capital development is timely and critical given the changing nature and requirements of work. Also, UNESCO (2015) acknowledges that the "skills conundrum" necessitates concerted policy efforts. In a regional policy seminar entitled Educating for the Fourth Industrial Revolution, UNESCO (2017) projected that, with fast technological and economic transformations, the skills gap would become a serious policy issue. In the same vein, the ILO (2011) observes, "New occupations are emerging and replacing others. Within each occupation, required skills and competencies are evolving" (p.1).

In Europe, following the Bologna Seminar on Doctoral Programmes for the European Knowledge Society, there was a concerted effort to ensure the responsiveness of the doctorate to the needs of the workplace, and to emerging demands of the economy more broadly (EUA, 2005, 2010). Subsequently the European Commission endorsed a set of Principles for Innovative Doctoral Training (EC, 2011). In Innovation Union, the European Union (EU) recommended that "Businesses should also be more involved in curricula development and doctoral training so that skills better match industry needs building for instance on the University Business Forum" (EU, 2011, p.9). These include research excellence, exposure to industry and other relevant employment sectors, and transferable skills training. The focus of doctoral education should be on preparing "future-ready" graduates, and enhanced skills training is posited at the key to this future. Addressing the problem of the skills gap is therefore at the core of the policy push to enhance the responsiveness of education systems in developed and developing economies alike.

\section{National Agendas: Industry-engaged Research}

In line with and in response to global concerns about the skills gap in research training, there is a trend in debates on research training in several national policy contexts. Commentaries published in leading academic news and views sites, ${ }^{1}$ including Chronicle of Higher Education, University Affairs, World University News, Times Higher Education, The Conversation, and Inside Higher Ed, highlight concerns regarding the value of the $\mathrm{PhD}$ and the skills gap in doctoral training. To meet emerging innovation needs and foster competitiveness, national policy actors are encouraged to take initiatives that support the development of requisite skills for the $21^{\text {st }}$ century. Reflecting the policy 
orientation towards doctoral work beyond the university sector within the European Higher Education Area, non-university research organizations such as Max Planck and Leibniz Institutes in Germany play major roles in the training of doctoral students. In 2017, there were over 3,300 doctoral students at a Max Planck Institute (DAAD, 2017). Across other OECD nations, including the U.S. (Jaschik, 2018; Walker et al., 2008), the UK (Taylor, 2012), Canada (Woolf, 2017) and Japan (Nature Editorial, 2017), the call for revamping the PhD entails combining research training with the development of employability skills.

In Australia, political interest in diversifying the doctorate and ensuring its "fitness for [the] knowledge economy" started over two decades ago (Usher, 2002). However, the economization of the PhD has intensified in recent times. National and institutional reports in Australia have underscored the value of quality research and research training for the economic productivity of the nation (ATN, 2017; Deloitte Access Economics, 2015; UA, 2015). The expectation is that through training skilled higher degree research graduates (e.g. PhD holders), Australian universities should play a role in improving the productivity of industries and thereby enhancing economic growth more broadly. In its call for improved investment on HE, Universities Australia (UA, 2015) stresses, "investments in university research are an investment in Australia's future prosperity" (p.6).

Illustrating the interactions and convergence between global and national policy spaces, the publication in 2013 of a major OECD report on science, technology and innovation (OECD, 2013) gave particular impetus to changes in Australia by placing the nation at the bottom of its ranking for university-industry collaboration. This unflattering ranking grabbed the attention of government and gave urgency to policy considerations. In 2015, with the aim of improving the competitiveness of Australian manufacturing industries, the Government established the Prime Minister's Industry 4.0 Taskforce, now renamed as Industry 4.0 Advanced Manufacturing Forum (Prime Minister's Industry 4.0 Taskforce 2017). The Forum collaborates with industry and universities to facilitate technological innovation for 'smart production'. Concern over the ranking provides further context for the Australian Council of Learned Academy's review of Australia's research training system (ACOLA, 2016), colouring its deliberations and the flavour of many of its recommendations. The final report of the ACOLA review reiterates the 'crisis discourse' and calls for new policy directions to improve university-industry engagement focused on PhD training. The report calls for development of an Australian Doctorate to meet $21^{\text {st }}$ century challenges (ACOLA, 2016). Among other considerations it advocates a scaling up of industry internship opportunities for HDR candidates along the lines of the Canadian MITACS scheme (MITACS, 2018).

Running simultaneously with the ACOLA review was a major review, chaired by lan Watt of the research funding block grants that supported university-based research and research training (DET, 2016). The Watt review handed down its report in May 2016. With respect to research training, the major recommendation, effective from the beginning of 2017, was that the three former block grants that had supported research training, each with distinctive remits, were to be consolidated into one. The government accordingly disestablished two existing and distinct scholarship funding block grants, the Australian Postgraduate Award (APA) and International Postgraduate Award Schemes (IPRS), and the Research Training Scheme (RTS), replacing all three with one consolidated grant called the Research Training Program (RTP). While the performance-based formula by which universities earned funding from this scheme differed somewhat from that which drove the former schemes, the government retained the focus and emphasis on completions, which continues as the main component of the higher degree by research funding formula with a $50 \%$ weighting. Through the new block grant, the government (DET, 2019) aims to support university-industry collaboration and produce job-ready graduates with skills relevant for diverse careers. 
The RTP allows greater levels of institutional discretion in the disposal of the consolidated grant than did the three distinct block grants it replaced. Where the distinct APA and IPRS schemes closely controlled the number and value of scholarship awards made and the government set the amount for general (non-scholarship) research training support through the RTS, the consolidated block grant permits universities significantly greater flexibility in the allocation of funds between scholarship and general support and in determining the value and duration of scholarship awards. One of the few prescriptions is that no more than $10 \%$ of the total scholarship investment may be directed to international candidates. The relatively higher levels of institutional discretion, long sought by the universities, have come with increased reporting requirements, to be phased in over several years. Under the RTP, universities must report on external supervision arrangements, with external or non-university supervisors serving as a proxy for industry engagement. Further reflecting the focus on future- and industry-ready graduates, universities must report on candidates' completion of attainments in professional and transferable skills training, over and above the research training provided through their formal programs. Reporting is also required on end-user engagement through mechanisms such as internships or industry-funded projects of all enrolled candidates (DET, 2019). These additional reporting requirements entail considerable adjustments to reporting systems for both universities and the government. Hence it seems likely that the government's interest in the take up of internships and industry-funded PhD research will emerge as more than a data collection exercise, and that funding tied to demonstrated levels of end-user engagement by $\mathrm{PhD}$ candidates is a real prospect in the future.

Thus, the Australian Government drove its agenda through a suite of measures and funding formulae to encourage greater levels of industry- and end-user engagement in PhD training. An ACOLA review implementation group was established, charged with translating all the recommendations into a workable implementation plan on a tight timeline, with key parts of the plan allocated to various players including the government, the universities, and peak bodies such as the Australian Council of Graduate Research and the Australian Industry Council. The government also sought to align the Watt-ACOLA outcomes with priorities outlined in the 2015 National Innovation and Science Agenda (NISA), a signature policy of the Prime Ministership of Malcolm Turnbull (2015-2018) (Cuthbert \& Sidelil, 2019).

Starting from 2017, the new research funding arrangements under the Research Training Program (RTP) encouraged greater research-industry collaboration. ${ }^{2}$ A significant outcome of the ACOLA implementation working group, jointly prepared by the Australian Council of Graduate Research and the Australian Industry Council, was a best practice guideline for industry, universities and candidates, governing industry and end-user cooperation in the training of PhD candidates (Australian Council of Graduate Research, 2018). Hopes were pinned on APR Intern as the lead initiative to achieve industry engagement by placing PhDs candidates with industry. New funding arrangements put in place in 2017 saw a total of $\$ 28.5$ million diverted from the RTP to APR Intern, which is run on behalf of the government by the Australian Mathematical Sciences Institute (AMSI n.d.). In fact, APR Intern is a re-badging of an earlier AMSI Intern program, which has run with a limited number of partner universities since 2002. Using a business model adapted from the MITACS scheme in Canada, APR Intern, like the AMSI Intern scheme it subsumed, sources internship opportunities from Australian industry, with government funding to assist industry to put on the interns and networks within universities to source PhD candidates with appropriate skills. With the push for internships that would see PhD candidates spending significant time with industry, it is clear that the Australia university sector is facing and negotiating challenges and potential disruptions to settled models of PhD delivery. In the next section, we examine some of the responses of universities to these challenges. 


\section{Institutional Responses: Revitalizing the PhD}

As noted in the foregoing sections, the current moment presents a convergence of views on the unfitness of the PhD to serve future labour market needs and, related to this, persistent concerns that research graduates are not future-ready and that the investment in doctoral education is not sufficiently aligned to economic and social imperatives. Global discourses (OECD, 2017a, 2017c, 2019; WEF, 2016; World Bank, 2018, 2019), national policy debates (ACOLA, 2016; DIISR, 2011; DIISRTE, 2012), and local employer expectations (Allen Consulting Group, 2010; Deloitte, 2018; Ernst \& Young, 2018; PwC Consulting, 2019) underscore the importance of making higher education responsive to emerging societal and market needs and aspirations. In response, national governments and university leaders have expressed commitment to revitalizing research training. Bentley and Meek (2018) provide an effective account of these policy pressures in their 2018 overview of doctoral education in Australia, but while they indicate that there is a variety of responses at the level of institutions and programs, they do not provide details.

In this section of the paper, we take a closer look at the program-level responses of selected Australian universities to national policy imperatives, which we argue reflect supra-national concerns. Reviewing developments in doctoral programs and research training in the period from 2014 to the present, we observe several key changes, clearly relating to priorities articulated by the Federal government or its agents, such as the ACOLA and Watt reviews. In Table 1, we provide an overview of the most salient changes. Notably, a range of programs across all three categories adopt ACOLA language in describing a shift of focus from $\mathrm{PhD}$ as product (thesis) to $\mathrm{PhD}$ as process, namely, the development of an independent research professional equipped to enter a range of industry sectors (ACOLA, 2016, p. 83). Our key finding is that the PhD revitalization efforts fall into three broad categories, with considerable overlap: transferable skills development; industry- and end-user engagement; and flexible pathways to the PhD. In what follows we briefly discuss these points in turn.

\section{Pro-skills PhD}

In the first category of program level descriptions of $\mathrm{PhD}$ doctoral programs, increased attention is being given to the provision of transferable or professional skills training. This recognises that many graduates will find employment beyond the university and research sectors. Perhaps the best exemplar of the pro-skills PhD to emerge in the period under examination is the PhD Xtra program being offered since 2016 by Deakin University, based in Melbourne and Geelong in the southern state of Victoria. The program description for $P h D X t r a^{3}$ shifts the language of doctoral training from product to process, and the focus of attention from the project to the professional. The branding reflects the doctoral Zeitgeist: the conventional PhD no longer completely meets the needs of stakeholders, something 'xtra' is required for $21^{\text {st }}$ century graduates. In South Australia, UniSA's Transformed $P h D$ again signals that what went before no longer meets contemporary and future needs. The new program promises to offer skill development and career preparation opportunities, university-industry collaborative supervision, industry-based mentoring, and adds an oral defence of thesis. As with Deakin and UniSA discussed here and many other Australian universities, the introduction of viva voce elements to the examination process is a significant re-calibration, as the viva is not traditionally part of the Australian doctoral examination process. Its inclusion is expressly designed to ensure that the candidate is examined, not just the thesis. The ACOLA report made repeated reference to the desirability of the viva (ACOLA 2016, pp.xvi, 65, 83, 84) as a means of better aligning doctoral examination processes to emerging expectations. 
Table 1. Examples of the PhD Reform in Australia; based on publicly available program-level descriptions on websites of respective universities

\begin{tabular}{|c|c|c|}
\hline Institutions & New PhD Programs & Key Changes \\
\hline $\begin{array}{l}\text { Deakin } \\
\text { University }\end{array}$ & $\begin{array}{l}\text { Deakin PhD Xtra } \\
(2016)\end{array}$ & $\begin{array}{l}\text { - Individual learning plans } \\
\text { - } \quad \text { Research methodology units } \\
\text { - } \quad \text { Career pathway placement } \\
\text { - Oral thesis examination (optional) } \\
\text { - } \quad \text { Portfolio of assets }\end{array}$ \\
\hline $\begin{array}{l}\text { La Trobe } \\
\text { University }\end{array}$ & $\begin{array}{l}\text { Industry PhD } \\
\text { (2016) }\end{array}$ & $\begin{array}{l}\text { - Industry-relevant research project } \\
\text { - } \quad \text { Collaborative funding } \\
\text { - } \quad \text { Collaborative supervision } \\
\text { - Industry placement }\end{array}$ \\
\hline $\begin{array}{l}\text { University of } \\
\text { South } \\
\text { Australia } \\
\text { [UniSA] }\end{array}$ & $\begin{array}{l}\text { The Transformed } \\
\text { PhD } \\
\text { (2016) }\end{array}$ & $\begin{array}{l}\text { - Skill development and career preparation opportunities } \\
\text { - University-industry collaborative supervisory panel } \\
\text { - Research end-users' engagement in mentoring doctoral } \\
\text { - } \text { Candidates } \\
\text { - Oral defence of thesis }\end{array}$ \\
\hline $\begin{array}{l}\text { University of } \\
\text { Technology } \\
\text { Sydney } \\
\text { [UTS] }\end{array}$ & $\begin{array}{l}\text { Industry Doctoral } \\
\text { Program (IDP) } \\
\text { (2016) }\end{array}$ & $\begin{array}{l}\text { - Real-world industry-based research project } \\
\text { - Industry Researcher Development Program (IRDP), } \\
\text { comprising Research Integrity and Ethnics, and Business } \\
\text { and Professional Modules }\end{array}$ \\
\hline $\begin{array}{l}\text { Monash } \\
\text { University }\end{array}$ & $\begin{array}{l}\text { Graduate Research } \\
\text { Industry } \\
\text { Partnerships (GRIP) } \\
\text { (2015) }\end{array}$ & $\begin{array}{l}\text { - Industry-oriented research projects } \\
\text { - Professional development programs (co-designed and } \\
\text { delivered with industry partners) } \\
\text { - Collaborative supervision of doctoral projects } \\
\text { (academics and industry specialists) } \\
\text { - Internship opportunities }\end{array}$ \\
\hline $\begin{array}{l}\text { University of } \\
\text { New England }\end{array}$ & $\begin{array}{l}\text { PhD.I (Doctor of } \\
\text { Philosophy- } \\
\text { Innovation) } \\
\text { (2016) }\end{array}$ & $\begin{array}{l}\text { - } \quad \text { Research learning program } \\
\text { - Innovation project portfolio } \\
\text { - Research projects with 'tangible innovation' and } \\
\text { 'identifiable impact' }\end{array}$ \\
\hline $\begin{array}{l}\text { Edith Cowan } \\
\text { University }\end{array}$ & $\begin{array}{l}\text { PhD (Integrated) } \\
(2016)\end{array}$ & $\begin{array}{l}\text { - Research and discipline-specific units (Year 1) } \\
\text { - Independent, supervised research project (Years 2-4) }\end{array}$ \\
\hline $\begin{array}{l}\text { Victoria } \\
\text { University }\end{array}$ & $\begin{array}{l}\text { PhD (Integrated) } \\
(2017)\end{array}$ & $\begin{array}{l}\text { - } \quad \text { Research training units and minor thesis (Year 1) } \\
\text { - Independent, supervised research project (Years 2-4) }\end{array}$ \\
\hline $\begin{array}{l}\text { University of } \\
\text { Wollongong }\end{array}$ & $\begin{array}{l}\text { PhD (Integrated) } \\
(2013)\end{array}$ & $\begin{array}{l}\text { - } \quad \text { Research and discipline-specific units (Year 1) } \\
\text { - Independent, supervised research project (Years 2-4) }\end{array}$ \\
\hline
\end{tabular}

In 2016 RMIT University in Melbourne reworked and re-orientated its long-standing skills development program from On Track to PhD Up program. ${ }^{4}$ Whereas the focus of On Track was on research-related skills (for example, time management, library skills), $P h D U p$ has a more ambitious agenda combining research-related with professional and transferable skills-development training. Again, the language is instructive: no longer content to keep candidates on track, the new pro-skills agenda aims to launch them into future careers. Somewhat against the tide, the University of 
Queensland, which boldly led the way some years earlier with its Career Advantage PhD (Cuthbert \& Molla, 2015), now appears to have retreated from this approach to a more traditional one in which the thesis is accompanied by a Career Development Framework aimed at building graduate attributes. The Framework offers compulsory and optional development opportunities under three key areas: research skills, transferable skills and professional skills. ${ }^{5}$ In other institutional programs, it is not always clear whether the skills training is included within the doctoral curriculum or in an enhanced set of offerings that runs alongside as a co-curricular provision.

\section{Industry- and End-user Engaged PhD}

The second category of developments in the period since 2014 complements the national research internship schemes (APR Intern and the earlier AMSI Intern) by emphasising industry and end-user engagement for $\mathrm{PhD}$ candidates, and in some cases providing new programs designed to achieve this. Many of the doctoral programs we reviewed in our research signal such an opportunity, whether through internships, work placements, or industry co-supervision. These emerging models of doctoral education are akin to the industry-oriented postgraduate training programs that have been run by Cooperative Research Centres (Cuthbert \& Molla, 2015). The Industry Doctoral Program (IDP) offered by UTS in Sydney leverages off a long-standing tradition of industry collaborations at this technical university, a key member of the Australian Technology Network grouping. The IDP is a four-year program in which the candidate works primarily with an industry partner. Under the mantle of its Industry Researcher Development Program (IRDP), the research component is supplemented by training which "provides knowledge and skills to effectively create, plan, negotiate outcomes and deliver on industry projects" ${ }^{6}$ In regional New South Wales, the University of New England at Armidale has introduced PhD.I (Doctor of Philosophy-Innovation), which combines research training units and an innovation project portfolio. The program, established in 2016, encourages research projects with "tangible innovation" and "identifiable impact".

The most distinctive offering to emerge to date, however, is Monash University's Graduate Research Industry Partnerships (GRIP) program. The key features which distinguish GRIP from other offerings are its partnership strategy, which is either via a segmented approach to industry (e.g. plastics manufacturing) or to a cluster of industries and sectors focused on a major challenge (e.g. water and sustainability in Asia), and its objective of assembling multi-disciplinary cohorts of 15-20 graduate research candidates to work with these partners. Monash has established an impressive range of GRIPs in the first few years of the program, with cohorts of PhD candidates currently working in partnerships in Behavioural Change, Food and Diary, Water and Sustainability in Asia, Chemical and Plastics Manufacturing, and Sustainable Public Transport. Further partnerships soon to recruit candidates include Digital and Data-driven Innovations in Health Care and Human in the Loop Analytics. ${ }^{7}$ On a different scale, the Industry and PhD Research Engagement Program (iPREP) in Western Australia (WA) runs as a consortium of all WA universities, with backing from the state government. Established in 2014, the scheme shares some of the same principles as GRIP but is offered as an adjunct to the formal PhD programs in individual universities. It aims to place small multi-disciplinary teams of PhD candidates with industry to work on defined projects that call for diverse skills and capabilities. The scheme has attracted over 50 industry partners and placed nearly 150 interns. ${ }^{8} \mathrm{~A}$ further example of the kinds of industry-linked PhD being encouraged by the new policy settings is the Industry PhD or iPhD program, established in 2018, and run through a partnership between University of New South Wales (UNSW) and CSIRO. The program "actively promotes collaboration between academia, industry and the research sectors" and aims at producing "research leaders who are work ready and understand the needs of industry" ${ }^{9} i P h D$ is a four-year program, with a minimum six-month industry internship. It is characterised as a threesided program that benefits from an investment of three parties: CSIRO, industry partner and university partner. The partnership aims to "deliver work-ready, industry-focussed researchers to bridge the research-industry divide". ${ }^{10}$ 
It is notable that while many universities may be seen to be re-orienting their research training programs towards industry- and end-user engagement, some of the boldest initiatives in this space come from the Group of Eight, research intensive universities, with Monash and UNSW being important exemplars. In this regard, the emphases of current policy on end-user engagement may be eroding the distinctions between the traditional research-intensive universities, such as those within the elite Group of Eight, and younger, technologically-focused universities, such as the universities within the Australian Technology Network, whose point of differentiation has been their industry focus. Another lens on this is provided by the 2019 Excellence in Research Australia Research (ERA) Engagement and Impact Assessment. The results of the first assessment of activities in the period commencing 2002 to 2016 shows a concentration of elite research universities dominating the top rankings (ARC, 2019).

\section{Flexible Pathways to the PhD}

The third set of developments in Australian PhD programs focuses on creating pathways to doctoral programs for candidates with no prior experience of research. This new development represents a response to the downturn in domestic demand for the $\mathrm{PhD}$; and the corresponding erosion of the Australian Honours program as the traditional point of entry to the PhD. The change is also associated with the calls, from government and the ACOLA review, for universities to engineer more accessible pathways to research for a range of non-traditional candidates, including professionals from business and industry (ACOLA 2016, pp, 99.100, 104). These routes of entry can take two forms: the Integrated PhD and a new hybrid Master of Research. Several universities, including Edith Cowan University in Western Australia (2017), Victoria University in Victoria (2017), and University of Wollongong (2013) in New South Wales have adopted the Integrated PhD model in which the first year of candidature is front-loaded with research enabling coursework, and the remaining three years are devoted to completion of the research project. The Integrated PhD is modelled on the UK "New Route" PhD (Park, 2005), and is intended to open doctoral programs to holders of predominantly coursework Masters degrees, including many international and sponsored candidates for whom the prospect of undertaking a second Master's degree with a substantial research component in order to meet standard PhD entry requirements is not attractive. Given the importance of international candidates to the research effort in Australian universities, especially in STEM subjects, the need for a mechanism to accommodate such applicants is understandable. Midcareer professionals from business and industry who seek research degrees but may not have the requisite academic credentials for admission represent another group of prospective candidates likely to benefit, and is one that the government is keen to encourage.

The Master of Research or MRes track, pioneered in Australia by Macquarie University in Sydney (and hence commonly known as the Macquarie Model), shares some of the objectives of the Integrated PhD. The Macquarie Model attempts to overcome the barriers engendered by the strictly bifurcated regulatory and funding regimes which govern coursework (taught programs) and higher degree by research programs in Australia. These barriers were an explicit issue of concern to the ACOLA review and recommendations to overcome them formed part of its final report (2016). The issue is that while undergraduate programs including the Honours year, a once dominant but now receding pathway to research, are available to students via Commonwealth Supported Places, many taught Masters' programs are available only on a fee-paying basis. Hence there is a user-pays gap between the subsidisation of undergraduate study and the higher degree by research programs for which tuition is covered by the RTP. One of the things the Macquarie model seeks to do is to take advantage of the increased appetite for Masters level study (relative to the decline in Honours) and to engineer a wholly government-subsidised route to research for local students. Another consideration at work here is global harmonisation, particularly alignment with the Bologna Process. The Macquarie model, with its 3-year undergraduate program plus the 2-year hybrid funded MRes 
followed by a 3-year PhD, comes close to the preferred Bologna Model of $3+2+3$, and does so in a funding landscape in which regulatory wrangling was required for its achievement.

It is worth noting that some of the changes at the program level are contentious and potentially disruptive. For instance, as a research-enabling program that prepares candidates to undertake doctoral training, the MRes draws in part on funding designed to support higher degrees by research. A MRes completion contributes a pro-rated outcome for the RTP funding formula which may be followed in three years by a PhD completion if the student proceeds. Some in the sector claim that this is double-dipping and watched with concern as Macquarie's Masters by Research enrolments grew by 300\% between 2013 and 2015. Nationally, the enrolment rate in Masters programs increased by only $3 \%$ over the same period (DET, 2017). Such an imbalance has significant financial implications for universities, given that the number of research degree completions determines the allocation of a fixed pool of RTP funding. Meanwhile the MRes model has been introduced at Western Sydney (2016) and the University of Wollongong (2016) and several more Australian universities are engaged in planning to make it available. This is an example of an internal disruption to doctoral education in Australia, prompted by the contradictory and sustained pressures of being asked to do more with less. The MRes "solution" is likely to produce more of the pressures it seeks to obviate down the line

\section{Problematic Assumptions}

At this point of our discussion, we identify three problematic assumptions underpinning policy discourses and institutional changes in relation to doctoral programs. The consensus is that the fastpaced technological progress and disruption have changed the nature of employment and employability. A recent Australian report has cautioned that a significant number of qualifications will become obsolete in the near future, leaving graduates with "more debt and poor job prospects" (Ernst \& Young, 2018, p.4). However, at the institutional level, the "employability discourse" Craswell, 2007) is being narrowly interpreted as one of transferable skills development. Much of the narrative on the problem of the unemployability of research graduates is linked to an assumed deficiency in transferable generic skills (ATN, 2017; Cuthbert \& Molla, 2015; Molla \& Cuthbert, 2015, 2016,2018 ), and institutional responses are aimed at improving the responsiveness of doctoral training to the perceived skills needs of the workplace. This raises the question of the extent to which the 'skills push' in PhD reform (Mowbray \& Halse, 2010) is aligned with the innovation push of the Industry 4.0 agenda. Transferable skills (e.g. communication, flexibility, teamwork, entrepreneurship, project management and leadership and an ability to adapt and learn in different work environments) are critical. But education (including the $\mathrm{PhD}$ ) should also enable people to thrive in the "age of discovery" (Goldin \& Kutarna, 2016), to live a meaningful life in the emerging "age of artificial intelligence" (OECD, 2019). Relatedly, the policy discourse regarding the PhD should move beyond the issue of graduate employability. It has been well documented that unemployment is not a serious problem among doctoral graduates (Cuthbert \& Molla, 2015; Jonker, 2016; McCarthy \& Wienk, 2019; Nature Editorial, 2017; Neumann \& Tan, 2011; OECD, 2014; UT-SGS, 2017; Woolston, 2018).

Much of the scientific literature focuses on academic practices in doctoral education (Boud \& Tennant, 2006; Manathunga et al., 2012) or the perceptions, experiences and attributes of doctoral graduates (e.g. Habel \& Whitman, 2016; Harman, 2002; Harman, 2004; Manathunga et al., 2009; Neumann, 2003; Platow, 2012). What remains unexplored is not only what sort of jobs are available outside academia for PhD graduates but also what sort of value doctoral graduates add in the sectors and industries beyond the academy in which they participate. Given how high the stakes are pitched in Industry 4.0 discourses, we wonder whether the questions that should be being asked are 
not just whether PhD graduates find work, but where: and what do we know about the value they add in these roles? It is timely and important to document where doctoral degrees in different disciplines lead in terms of jobs and economic sectors in Australia. A more systematic approach to collecting and disseminating data on PhD outcomes can "form a vital feedback loop, one that is directed to toward the government and employers, and the other one that reaches back toward graduate schools" (Nature Editorial, 2017, p.249). Australia's Chief Scientist is optimistic that PhD graduates bring value in a number of fields and points in particular to successful "cross overs", such as physics PhDs in financial services (Office of the Chief Scientist, 2016)-or we would add social science PhDs in digital industries. However, much of this argument remains impressionistic and anecdotal.

Our second point is that in some cases the rebranding of doctoral programs does not take the time factor into consideration. Adding more tasks without extending the period of candidature (e.g. the up to six months of career pathway placement allowed as part of Deakin's PhD Xtra) diminishes the amount of time available for the research work. Will doctoral graduates have enough time under the new programs to acquire specialist knowledge and research competence? Doctorate readiness involves "mastery of the subject; mastery of analytical breadth (where methods, techniques, contexts and data are concerned) and mastery of depth (the contribution itself, judged to be competent and original and of high quality)" (UK Council for Graduate Education, 1997, p.15). If transferable skills training is to take greater prominence in doctoral programs, it is imperative that universities carefully consider implications for the quality and length of core research training.

Finally, the implications of the ongoing restructuring for international research students has not been dealt with clearly. In 2015 over a quarter of doctoral graduates in OECD countries were international students (OECD, 2017a, p.65) and Australia is one of the top destinations for such students. In 2016, the education of international students by Australian institutions was the country's third highest export, estimated at over $\$ 28$ billion. Over 150 thousand international students were enrolled in postgraduate courses, including doctoral programs (UA, 2018). As Santos et al (2016) have persuasively argued, many of the debates signalling the 'crisis' in doctoral education in advanced HE systems, especially the supply and demand inflected claim that we are producing "too many PhDs", do not translate to developing and emerging HE systems that are in the process of growing their capabilities for both research and innovation. Given the global reach of doctoral education, any significant change with respect to the $\mathrm{PhD}$ within a national system needs to be cognizant of this reality.

\section{The Doctorate as a Capability}

Industry 4.0 discourse highlights 'deep shifts' in the global economic and technological order (Schwab, 2017), and emphasizes the skills gap as a major problem. The argument is that we live in a time of rapid change and qualifications that are valued today become obsolete tomorrow. If this assessment is correct, how can we develop researchers who can succeed in a world where machines represent a considerable portion of the workforce? The combined force of human capital theory and neoliberal policy logic in education policy has resulted in an aggressive push for 'work ready' research graduates. For proponents of human capital theory (Becker, 1962, 1993; Heckman, 2013, Schultz, 1961; World Bank 1999, 2019), education equips people with marketable skills, enhances their job performance, and increases their overall productivity and life chances. The human capital argument for education is that "a greater level of education results in higher labor productivity [and] higher rate of aggregate growth" (Goldin \& Katz, 2008, p.2). Viewed from this perspective, PhD programs are assessed in relation to the extent to which they enable graduates to be employable and productive. A strong belief in the power of market principles means that neoliberalism shifts the 
responsibility for education from the state to the individual, and a public good becomes an individual consumer commodity. In the words of Wendy Brown:

Neoliberalization replaces education aimed at deepening and broadening intelligence and sensibilities, developing historical consciousness and hermeneutic adroitness, acquiring diverse knowledge and literacies, becoming theoretically capacious and politically and socially perspicacious, with education aimed at honing technically-skilled entrepreneurial actors adept at gaming any system. (Brown, 2011, p.123)

The skills gap logic that informed the policy discourse at the global, national and institutional levels narrowly focuses on the instrumental values of education. Research training is increasingly aligned with corporate interests; research graduates are viewed as potential entrepreneurs to generate wealth and jobs for others. As a result, universities are under constant pressure to keep pace with changes in the economy, and to produce a "future-ready" research and innovation workforce that adapts to the needs of the global knowledge economy. We argue that the instrumentalist framing of the $\mathrm{PhD}$ as a form of human capital is too narrow. In her influential book, The New Education, Cathy Davidson stresses: "The goal of higher education is greater than workforce readiness. It's world readiness" (Davidson, 2017, p.27, emphasis in original). We would ask this question of emerging doctoral programs: beyond equipping graduates with skills and knowledge relevant to the workplace, do they enlarge substantive freedoms of graduates in terms of enabling them to realise their full potential not just to be productive at work?

We suggest that there is a need to reinvigorate the theoretical framework informing research training programs, including the $\mathrm{PhD}$. We contend that skills per se are not what is needed for future work readiness but capabilities to acquire knowledge and skills as required. Specifically, we propose that the doctorate should be viewed as a measure and an enabler of human capability, not just as a proxy for human capital. Human capital and human capability are not necessarily antithetical (Sen, 1997); the difference between the two as evaluative frames lies mostly in their scope. Whereas human capital logic focuses on the productivity of individuals as part of the labour force, a capability-based assessment of human development concerns itself with what people are able to be and do in relation to what they have reason to value (Sen 1999, 2000). Human development is a process of enlarging freedom through cultivating relevant expertise and skills; it manifests in people's agency and choice.

Seen from the capability perspective, the $\mathrm{PhD}$ should provide graduates with substantive opportunities to be and do what they reflectively value in their own life and in society (Drèze \& Sen, 2002), and prepare them to be responsive to emerging challenges and opportunities. Given the high level of education entailed in the PhD, graduates should also be ideally positioned to provide enabling leadership for others in the attainment of their goals, whether this is at local or community levels, within the professions, the academy and industry, or in more formal political roles at national and regional levels. Human contributions to society are not limited to economic productivity. Hence the value of the PhD should be assessed in terms of the extent to which it supports people to be and do what they have reason to value in their lives and communities - ultimately, "economic prosperity is no more than one of the means to enriching the lives of people" (p.4). Well-educated citizens possess valuable attributes such as creativity, flexibility, reflectivity, and adaptability, and are more likely to engage in public reasoning, stimulate social changes and actively participate in democratic processes (Unterhalter, 2009). Hence the PhD should be relevant to produce "capable humans not just skill sets for the workplace" mainly because "we live in societies, not just economies" (Bryson, 2010, p.2). The issue at hand is therefore whether or not the current changes in the PhD (in Australia and worldwide) enable individuals to be and do what they have reason to value in the context of fast-paced changes of work and ways of working. It is also worth noting that there is no reliable way 
of knowing the responsiveness of a newly graduated $\mathrm{PhD}$ holder to the skills needs of the emerging Industry 4.0 economy. To return to a point made earlier, in the absence of any real understanding of the value currently added by PhD graduates in various industry sectors, over and above that added by other graduates, measuring the responsiveness of the new programs to emerging needs of the labour market presents a further challenge. As a result, beyond the political debate, expectations of key stakeholders regarding contents, delivery apparatus and purposes of the PhD remain vague and uncertain.

Also, a capability-driven research training model stresses the importance of the fair distribution of social opportunities such as education. As the policy debate focuses on the economic contributions of the PhD, the social justice implications of unequal participation in higher degree by research (HDR) programs is neglected. If rising inequality is linked with inequalities in knowledge and skills (Dorling, 2015; Piketty, 2014; The Economist, 2015), the policy response needs to include widening access to higher education and to high-return qualifications such as the PhD. Over two decades ago, in The End of Work, Rifkin (1995) cautioned:

If the dramatic productivity gains of the high-tech revolution are not shared, but rather used primarily to enhance corporate profit, to the exclusive benefit of stockholders, top corporate managers, and the emerging elite of high-tech knowledge workers, chances are that the growing gap between the haves and the have-nots will lead to social and political upheaval on a global scale. (p.13)

What is missing in the Industry 4.0 discourse in the global policy space and in the industry engagement debates at national and institutional levels is the public responsibility in cultivating social-minded knowledge workers. It is imperative to recognise that human development necessitates a collective commitment. It is "the development of the people through building human capabilities, by the people through active participation in the processes that shape their lives and for the people by improving their lives" (UNDP, 2016, p.2, emphasis added). Hence social arrangements such as education policies and strategies should be primarily assessed on the basis of substantive opportunities they provide to people to choose the life they value.

Finally, as economic productivity and competitiveness increasingly depend on the creation, production, distribution and consumption of knowledge, investment in research training has become a key agenda in global and national policy spaces. However, the capability approach to research training also recognises that human development has an empowering effect. People with advanced knowledge and skills (such as PhD holders) are more likely to play vital roles in organising politically and challenging oppression and inequality in society (Boni \& Walker, 2016; Drèze \& Sen, 2002; Walker \& Fongwa, 2017; Walker \& McLean, 2013). The capability perspective emphasizes that people need not only access to resources and opportunities, but also the ability to convert these into valuable and valued achievements and pursue goals they set for themselves and their communities. In Unger's (2019) words, education for inclusive knowledge economy should equip graduates "with the instruments with which both to move within the existing order of society and culture and to resist, transcend, and revise that order" (p.55). Relatedly, a research training program that helps candidates to succeed in an uncertain world focuses on human development rather than skills acquisition. Such a program would recognise diverse needs, aspirations and identities of candidates, and involve them in decisions regarding what they learn, how they learn and why they learn. In other words, research training programs may be valued in a range of dimensions beyond the economic. As Sen (2003) argues, if life is seen as a set of 'doings and beings' that are valuable, evaluating the quality of life starts with assessing people's capability to be and do what they have reason to value. 


\section{Conclusion}

In this paper we set out to document institutional responses in Australia to policy imperatives for transformation of the $\mathrm{PhD}$ to ensure that graduates and the nation are prepared for the new world of work and economic conditions being framed as Industry 4.0. The discursive shift from the knowledge economy to the Fourth Industrial Revolution has implications for research degree training but our analysis of Australian responses suggest that the changes to doctoral programs are not commensurate with the enormity of the transformation being foreshadowed in Industry 4.0 discourse. Economic accounts of the value of higher education in general and the PhD in particular narrowly frame value in terms of economic productivity and the net worth of an individual via modelling of lifetime earnings. If we are reading the imperatives of Industry 4.0 correctly and, just as importantly, are attuned to the massive transformations this revolution will entail, it is clear that more is needed than enhanced workplace skills. In order for highly educated individuals to be prepared to lead communities, nations and regions through the changes that are already upon us and will surely accelerate, education (including the PhD) should cultivate capability. The multiple valency of the term innovation makes this clear: what is the opportunity for disruption, business and industrial transformation and wealth generation for some, represents job loss, the loss of whole industrial sectors, poverty and alienation for others.

At the core of workforce capability is agility, which is expressed in the ability of workers to respond successfully to continual and accelerated change in technological innovation. If the central purpose of the PhD is framed as training future knowledge workers, exactly how universities should go about equipping them with relevant knowledge and skills is not yet clear. Anticipating with a degree of certainty what skill sets are required for future jobs is nearly impossible. Hence, research training programs (including the PhD) need to focus broadly on human development that expands people's freedom of choice, widens career opportunities and promotes civic engagement (Drèze \& Sen, 2002) and instils among other things a disposition and capability for future learning. Earlier economic revolutions also tell us this. Economic transformation, that is, a fundamental change in the way wealth is generated and distributed, and in who gets to participate in the economy and who is excluded, does not come without huge social and political upheaval. In other words, significant economic transformation is not restricted to the economic realm, but stands in a complex relationship with social, political and environmental changes. Schwab (2017) warns that without adequate policy (and we would add education and leadership), the prospect of dramatic change entailed in the Fourth Industrial Revolution brings the risk of great inequality and political instability.

We find the instrumental approach to the PhD and research training, and institutional efforts to accommodate this, at least as we have examined them in Australia, to fall far short of what is needed. We suggest that a capability-based account of the PhD is expansive in the sense that it recognises the economic and social benefits of research training both at individual and societal levels and may provide a starting point for a more ambitious agenda for the reform and re-cultivation of the PhD along different lines from the current instrumental focus on the economy and labour force. High level research capabilities should not be reduced to a set of marketable skills, although, of course, the skills of these graduates should be marketable. The capabilities called for by the Fourth Industrial revolution are not only those mandated by the revolution-the STEM-centred skills which enable technological advances, for example. They are also the capabilities required to anticipate and manage its economic, social and political implications, to reconcile its human costs and benefits, to lead and govern communities disrupted and disenfranchised by change, and to ensure a more just distribution of the wealth and opportunities this revolution may bring. We urge those involved in the 
design and delivery of doctoral education, and those developing the policy settings in which this takes place, to think beyond the prevalent economisation of the $\mathrm{PhD}$ and to mobilise a more inclusive vision for its role in Industry 4.0. The doctorate

\section{Notes}

\footnotetext{
${ }^{1}$ Examples of commentaries on the value of the PhD published on academic news and views sites can be found at https://www.chronicle.com/article/How-PhDs-Romanticize-the/245423 (USA); https://www.universityaffairs.ca/career-advice/beyond-the-professoriate/response-u-ts-10000-phds-project/ (Canada); https://www.universityworldnews.com/post.php?story=20170410230128288 (Sweden); https://www.timeshighereducation.com/blog/exactly-how-valuable-phd (UK); https://theconversation.com/its-time-to-reduce-the-number-of-phd-students-or-rethink-how-doctoralprograms-work-68972 (Australia); and https://www.insidehighered.com/digital-learning/blogs/technologyand-learning/what-should-be-terminal-degree-our-new-field-learning (USA).

${ }^{2}$ See https://www.education.gov.au/sharper-incentives-university-industry-engagement-throughstreamlining-university-research-block

${ }^{3}$ See https://www.deakin.edu.au/research/become-a-research-student/phd-xtra

${ }^{4}$ See PhD Up program. Retrieved 11 March 2019, from https://www.rmit.edu.au/students/studentessentials/information-for/research-candidates/enriching-your-candidature/phd-up-program

${ }^{5}$ See details of the Framework at https://cdf.graduate-school.uq.edu.au. Part of the description reads: "Developed in consultation with industry, the Career Development Framework provides you with a holistic approach to research training covering topics such as research integrity, networking, communication skills and inter-cultural communication, writing skills, teamwork, CV writing, entrepreneurship, business acumen, resilience and emotional intelligence".

${ }^{6}$ Details of the UTS-Industry Doctorate Program can be found at https://www.uts.edu.au/research-andteaching/our-research/industry-partnerships/ways-engage/uts-industry-doctorate-program

${ }^{7}$ See full program description of Monash GRIPS at https://www.monash.edu/graduate-research/futurestudents/phd/interdisciplinary for further details on industry partnerships associated with the PhD

${ }^{8}$ Details can be found at https://www.iprep.edu.au

${ }^{9}$ See the website of the program at https://www.csiro.au/en/Careers/Student-and-graduateopportunities/Industry-PhD

${ }^{10}$ See details at https://inspiringnsw.org.au/2017/12/04/introducing-iphd/
}

\section{Acknowledgements}

The authors are grateful to Dr Kay Dreyfus for her editorial assistance in preparing this article for publication. We would also like to thank the two anonymous reviewers for their constructive feedback.

\section{References}


ACOLA [Australian Council of Learned Academies]. (2016). Review of Australia's research training system. Melbourne: ACOLA.

Allen Consulting Group. (2010). Employer demand for researchers in Australia (final report). Canberra: Author.

AMSI [Australian Mathematical Science Institute]. n.d. APR [Australian Postgraduate Research] Intern. Retrieved on 18 January 2019 from https://aprintern.org.au/

Andres, L., Bengtsen, S. S. E., Castaño, P. G., Crossouard, B., Keefer, J. M., \& Pyhältö, K. (2015). Drivers and interpretations of doctoral education today: National comparisons. Frontline Learning Research, 3(3), 5- 22.

ARC [Australian Research Council]. (2019). Engagement and Impact Assessment. 2018-19. National Report. Accessed on 30 April 2019 from https://dataportal.arc.gov.au/El/NationalReport/2018/

ATN [Australian Technology Network of Universities]. (2017). Enhancing the value of PhDs to Australian industry. Canberra: ATN.

Australian Council of Graduate Research. 2018. Enhancing industry university engagement through graduate research students: a guide for industry. Retrieved on 20 Feb 2019, from https://www.acgr.edu.au/wp-content/uploads/2018/10/industry-engagement-2.pdf

Baldwin, R. (2019). The globotics upheaval: Globalization, robotics, and the future of work. Oxford: Oxford University Press

Barnett, J. V., Harris, R. A., \& Mulvany, M. J. (2017). A comparison of best practices for doctoral training in Europe and North America. FEBS Open Bio, 7, 1444-1452.

Bauerlein, M. (2008). The dumbest generation: How the digital age stupefies young Americans and jeopardizes our future (or, don't trust anyone under 30). New York: Tarcher.

Becker, G. (1962). Investment in human capital: a theoretical analysis. The Journal of Political Economy, 70(5), 9-49.

Becker, G. (1993). Human capital: A theoretical and empirical analysis with special reference to education (3rd ed.). Chicago: The University of Chicago Press.

Bentley, P. J., \& Meek, V, L. (2018). Development and future directions of Higher Degree Research training in Australia. In J. C. Shin, B. M. Kehm \& G. A. Jones (Eds.), Doctoral education for the knowledge society: Convergence or divergence of national approaches (pp.123-146). Cham: Springer.

Boni, A., \& Walker, M. (2016). Universities and global human development: Theoretical and empirical insights for social change. London: Routledge.

Boud, D., \& Tennant, M. (2006). Putting doctoral education to work: Challenges to academic practice. Higher Education Research \& Development, 25(3), 293-306.

Brown, M. (2017). The myth of future jobs: Why university qualifications still matter in the digitalera. https://www.linkedin.com/pulse/myth-future-jobs-why-university-qualifications-stillmatter-brown/

Brown, W. (2011). Neoliberalized knowledge. History of the Present, 1(1), 113-129.

Brynjolfsson, E., \& McAfee, A. (2016). The second machine age: Work, progress, and prosperity in a time of brilliant technologies. New York: W.W. Norton \& Company.

Bryson, J. (2010). Beyond skill: An introduction. In J. Bryson (Ed.), Beyond skill: Institutions, organisations and human capability (pp.1-8). Hampshire: Palgrave Macmillan

Caplan, B. (2018). The case against education: Why the education system is a waste of time and money. Princeton: Princeton University Press.

Chevalier, A., Harmon, C., Walker, I., \& Zhu, Y. (2004). Does Education Raise Productivity, or Just Reflect It? The Economic Journal, 114(499), pp. F499-F517.

Cowan. P. (2017). Are 'edusceptics' right to portray higher education as a big con? Times Higher Education, 2 November. Retrieved on 17 February 2019 from https://www.timeshighereducation.com/features/are-edusceptics-right-portray-highereducation-big-con 
Craswell, G. (2007). Deconstructing the skills training debate in doctoral education. Higher Education Research \& Development, 26(4), 377-391.

Cuthbert, D., \& Molla, T. (2015). PhD Crisis Discourse: A critical approach to the framing of the problem and some Australian 'solutions'. Higher Education, 69(1), 33-53.

Cuthbert, D., \& Sidelil, L. (2019). Gender equity instrumentalism and (re)building the nation through innovation: Critical reflections on women and STEM policy in Australia. In D. E. Neubauer \& S. Kaur (Eds.), Gender and the changing face of higher education in Asia Pacific (pp.57-71). Switzerland: Palgrave Macmillan.

DAAD [Deutscher Akademischer Austauschdienst (German Academic Exchange Service)]. (2017). The German research landscape. Frankfurt: DAAD. You need German name here to fit acronym.

Davidson, C. N. (2017). The new education: How to revolutionize the university to prepare students for a world in flux. New York: Basic Books.

Deloitte Access Economics. (2015). The importance of Universities to Australia's prosperity. Canberra: Deloitte Access Economics

Deloitte Access Economics. (2018). The Fourth Industrial Revolution is here-are you ready? London: Deloitte Development LLC.

DET [Department of Education and Training]. (2016). Review of Research Policy and Funding Arrangements. Canberra: Australian Government.

DET [Department of Education and Training]. (2017). Research training implementation plan. Canberra: Commonwealth of Australia.

DET [Department of Education and Training]. (2019). Research Training Program details and conditions of grants. Accessed on 9.02.2019 at: https://docs.education.gov.au/system/files/doc/other/2019_rtp_details_and_conditions_of_ grants.pdf

DIISR [Department of Innovation, Industry, Science and Research]. (2011). Research skills for an innovative future: A research workforce strategy to cover the decade to 2020 and beyond. Canberra: Commonwealth of Australia.

DIISRTE [Department of Innovation, Industry, Science, Research and Tertiary Education]. (2012). National research investment Plan. Canberra: Commonwealth of Australia.

Dorling, D. (2015). Injustice: Why social inequalities persist ( $2^{\text {nd }}$ ed.). Bristol: The Policy Press.

Drath, R., \& Horch, A. (2014). Industrie 4.0: hit or hype? IEEE Industrial Electronics Magazine, 8(2), pp.56-58.

Drèze, J., \& Sen, A. (2002). India: Development and participation (2nd ed.). Oxford: Oxford University Press.

Dunlop, T. (2016). Why the future is workless. Sydney: NewSouth Books.

EU [European Union]. (2011). Europe 2020 Flagship Initiative Innovation Union. Luxembourg: Publications Office of the European Union.

EC [European Commission]. (2011). Principles for innovative doctoral training. Brussels: EC.

Ernst \& Young. (2018). Can the universities of today lead learning for tomorrow? The University of the Future. XXXX: Ernst \& Young.

EUA [European University Association]. (2010). Salzburg II recommendations: European universities' achievement since 2005 in implementing the Salzburg principles. Brussels: EUA.

EUA [European University Association]. (2005). Bologna Seminar on Doctoral Programmes for the European Knowledge Society, Salzburg, 3-5 February 2005: Conclusions and recommendations. Retrieved on 12 January 2019 from https://www.eua.eu/downloads/publications/salzburg\%20recommendations\%202005.pdf

Frey, C.B., \& Osborne, M.A. (2013). The future of employment: How susceptible are jobs to computerization? Oxford: University of Oxford.

Gokhberg, L., Shmatko, N., \& Auriol, L. (Eds.) (2016). The science and technology labor force: The value of doctorate holders and development of professional pareers. Cham: Springer. 
Goldin, C., \& Katz, L. F. (2008). The race between education and technology. The Cambridge, MA.: Belknap Press of Harvard University Press.

Goldin, I., \& Kutarna, C. (2016). Age of discovery: Navigating the risks and rewards of our new renaissance. London: Bloomsbury.

Habel, C., \& Whitman, K. (2016). Opening spaces of academic culture: Doors of perception; heaven and hell. Higher Education Research \& Development, 35(1), 71-83.

Harman, G. (2002). Producing PhD graduates in Australia for the knowledge economy. Higher Education Research \& Development, 21(2), 179-190.

Harman, K. M. (2004). Producing 'industry-ready' doctorates: Australian Cooperative Research Centre approaches to doctoral education. Studies in Continuing Education, 26(3), 387-404.

Heckman, J. (2013). Giving kids a fair chance. Boston: The MIT Press.

Hollingsworth, R. (2017). Higher education: The making of US academia., Nature, 541, 461-462.

ILO [International Labour Organization]. (2011). A Skilled Workforce for Strong, Sustainable and Balanced Growth: A G20 Training Strategy. Geneva: International Labour Office.

Jaschik, S. (2018). The Ph.D. skill mismatch. Inside Higher Ed. January 5, http://www.insidehighered.com/news/2018/01/05/study-shows-academic-job-searcheslanguages-value-alt-ac-skills? $\mathrm{mc}$ _cid $=5 \mathrm{f7} 7848 \mathrm{e} 8 \mathrm{ff} \& \mathrm{mc}$ _eid=0b08cade43

Jonker, L. (2016). Ontario's PhD graduates from 2009: Where are they now? Higher Education Quality Council of Ontario (HEQCO) April 26, 2016

Lingard, B, \& Rawolle, S. (2011). New scalar politics: Implications for education policy. Comparative Education, 47(4), 489-502.

McCarthy, P. X., \& Wienk, M. (2019). Advancing Australia's knowledge economy: Who are the top PhD employers. Melbourne: AMSI and CSIRO.

Manathunga, C., Pitt, R., \& Critchley, C. (2009). Graduate attribute development and employment outcomes: tracking PhD graduates. Assessment \& Evaluation in Higher Education, 34(1), 91103.

Manathunga, C., Pitt, R., Cox, L., Boreham, P., Mellick, G., \& Lant, P. (2012). Evaluating industrybased doctoral research programs: Perspectives and outcomes of Australian Cooperative Research Centre graduates. Studies in Higher Education, 37(7), 843-858.

Mitacs. (2018). Mitacs annual report: Innovation, Science and Economic Development Canada 2017/18: Ottawa; Mitacs.

Molla, T., \& Cuthbert, D. (2018). Re-imagining Africa as a knowledge economy: Premises and promises of recent higher education development initiatives. Journal of Asian and African Studies, 53(2), 250-267.

Molla, T., \& Cuthbert, D. (2016). In pursuit of the African PhD: A critical survey of emergent policy issues in select sub-Saharan African nations, Ethiopia, Ghana and South Africa. Policy Futures in Education, 14(6), 635-654.

Molla, T., \& Cuthbert, D. (2015). The Issue of Research Graduate Employability in Australia: An Analysis of the Policy Discourse (1999-2013). The Australian Educational Researcher, 42(2), 237-256.

Mowbray, S., \& Halse, H. (2010). The purpose of the PhD: Theorising the skills acquired by students. Higher Education Research \& Development, 29(6), 653-664.

Nature Editorial. (2017). Many junior scientists need to take a hard look at their job prospects. Nature, 550, 429 (26 October 2017) doi:10.1038/550429a

Neumann, R. (2003). The doctoral education experience: Diversity and complexity. Canberra: Commonwealth of Australia.

Neumann, R., \& Tan, K. K. (2011). From PhD to initial employment: The doctorate in a knowledge economy. Studies in Higher Education, 36(5), 601-614.

OECD. (2012). Science, technology and industry outlook 2012. Paris: OECD Publishing.

OECD (2013). Science, technology and innovation scorecard 2013. Paris: OECD Publishing. 
OECD. (2014). Who are the doctorate holders and where do their qualifications lead them?. Education Indicators in Focus, No. 25. http://dx.doi.org/10.1787/5jxv8xsvp1g2-en

OECD (2017a), Education at a Glance 2017: OECD Indicators, OECD Publishing, Paris. http://dx.doi.org/10.1787/eag-2017-en

OECD (2017b). OECD digital economy outlook. Paris: OECD Publishing.

OECD (2017c). OECD Skills Outlook 2017: Skills and Global Value Chains, OECD Publishing, Paris,

OECD. (2018a). Getting skills right: Australia. Paris: OECD Publishing.

OECD. (2018b). The future of education and skills: Education 2030. Paris: OECD Publishing.

OECD. (2019). Trends shaping education 2019. Paris: OECD Publishing.

Office of the Chief Scientist. (2016). Australia's STEM workforce. Canberra: Common Wealth of Australia.

Park, C. (2005). New Variant PhD: The changing nature of the doctorate in the UK. Journal of Higher Education Policy and Management, 27(2), 189-207.

Piketty, T. (2014). Capital in the Twenty-First Century (Trans. A. Goldhammer). Cambridge, MA: The Belknap Press of Harvard University Press.

Platow, M. J. (2012) PhD experience and subsequent outcomes: A look at self-perceptions of acquired graduate attributes and supervisor support. Studies in Higher Education, 37(1), 103118.

Prime Minister's Industry 4.0 Taskforce. (2017). Industry 4.0 Testlabs in Australia: Preparing for the future. Canberra: Department of Industry, Innovation and Science.

PwC Consulting (Australia). (2019). Transforming Australian manufacturing: Preparing businesses and workplaces for Industry 4.0. Melbourne: PwC Consulting.

Rifkin, Jeremy (1995). The end of work: The decline of the global labor force and the dawn of the post-market era. New York: Putnam.

Rizvi, F., \& Lingard, B. (2010). Globalizing education policy. London: Routledge.

Robertson, S., \& Dale, R. (2016). Comparing policies in a globalising world: Methodological reflections. In A. Hadjar \& C. Gross (Eds.), Education systems and inequalities (pp.33-50). Bristol: Policy Press.

Ryan, J. (2012). Internationalisation of doctoral education: Possibilities for new knowledge and understandings. Australian Universities' Review, 54(1), 55-63.

Santos, J. M., Horta, H., \& Heitor, M. V. (2016) "Too many PhDs? An invalid argument for countries developing their scientific and academic systems: The case of Portugal", Technological Forecasting and Social Change, 113(Part B): 352-362.

Schultz, T. W. (1961). Investment in human capital. The American Economic Review, 51(1), 1-17.

Schwab, K. (2016). The Fourth Industrial Revolution: What It Means and How to Respond. Foreign Affairs, 12 December 2015.

Schwab, K. (2017). The Fourth Industrial Revolution. New York: Crown Business

Sen, A. (1997). Human capital and human capability." World Development, 25(12), pp.1959-1961.

Sen, A. (2003). Development as capability expansion. In S. Fukudo-Parr \& A. K. S. Kumar (Eds.), Readings in human development (pp. 41-58). New Delhi: Oxford University Press.

Sen, A.K. (1999). Development as freedom. Oxford: Oxford University Press.

Shin, J. C., Kehm, B. M., \& Jones, G. A. (Eds.) (2018). Doctoral education for the knowledge society: Convergence or divergence in national approaches? Cham: Springer.

Sykes, C. J. (2016). Fail U.: The false promise of higher education. New York: St. Martin's Press.

Taylor, S. E. (2012). Changes in doctoral education: Implications for supervisors in developing early career researchers. International Journal for Researcher Development, 3(2), 118-138.

The Economist. (2015). Education and class: America's new aristocracy. 24 January.

UA [Universities Australia]. (2015). Keep it clear: A policy statement 2016. Canberra: UA.

UA [Universities Australia]. (2018). Data snapshot 2018. Canberra: UA.

UK Council for Graduate Education. (1997). Practice-based doctorates in the creative and performing arts and design. Coventry: UK Council for Graduate Education. 
UNDP [United Nations Development Program]. (2016). Human development report 2016: Human development for everyone. New York: UNDP.

UNESCO. (2015). UNESCO Science Report: towards 2030. Paris: UNESCO Publishing.

UNESCO. (2017). Educating for the 4th Industrial Revolution: 2017 UNESCO-KEDI Asia-Pacific Regional Policy Seminar - Concept note. Retrieved 23 February 2019 from https://teams.unesco.org/ORG/fu/bangkok/public_events/Shared\%20Documents/IQE/2017/0 9-KEDI/docs/unesco-kedi-policy-seminar-2017-concept-note.pdf

Unger, R. M. (2019). The knowledge economy. London: Verso.

Unterhalter, E. (2009). Education. In S. Deneulin \& L. Shahani (Eds.), Introduction to the human development and CA. freedom and agency (pp. 207-227). London: Earthscan.

Usher, R. (2002). A diversity of doctorates: Fitness for the knowledge economy? Higher Education Research \& Development, 21(2), 143-153.

UTS. (n.d.) UTS-Industry Doctorate Program. Retrieved 11 March 2019, from https://www.uts.edu.au/research-and-teaching/our-research/industry-partnerships/waysengage/uts-industry-doctorate-program

UT-SGS [University of Toronto-School of Graduate Studies]. (2017). Employed and engaged: An overview of the 10,000 PhDs project. Retrieved from http://www.sgs.utoronto.ca/Documents/SGS_Overview_10KPhDsProject.pdf, 18 February 2019.

Walker, G. E., Golde, C. M., Jones, L, Bueschel, A. C., \& Hutchings, P. (2008). The formation of scholars: Rethinking doctoral education for the twenty-first century. San Francisco: JosseyBass.

Walker, M., \& Fongwa, S. (2017). Universities, employability and human development. London: Palgrave Macmillan.

Walker, M., \& McLean, M. (2013). Professional education, capabilities and the public good. London and New York: Routledge.

WEF [World Economic Forum]. (2016). The future of jobs. Employment, skills and workforce strategy for the Fourth Industrial Revolution. Geneva: WEF.

Whitaker, R. W. (2004). Why Johnny can't think: America's professor-priesthood. North Augusta: Kudzu media.

Woolf, D. (2017). An alternative, industry-linked model for PhD training. Retrieved on 21 March 2018, from https://www.universityaffairs.ca/opinion/in-my-opinion/alternative-industrylinked-model-phd-training/

Woolston, C. (2018). PhD career paths hold promise. Nature, 555, p.277

World Bank. (1999). World development report 1998/99: Knowledge for development. Oxford: Oxford University Press.

World Bank. (2011). Learning for All: Investing in People's Knowledge and Skills to Promote Development-World Bank Group Education 2020 Strategy. Washington DC: The World Bank.

World Bank. (2018). World Development Report 2018: Learning to realize education's promise. Washington DC: The World Bank.

World Bank. (2019). World Development Report 2019: The changing nature of work. Washington DC: The World Bank. 